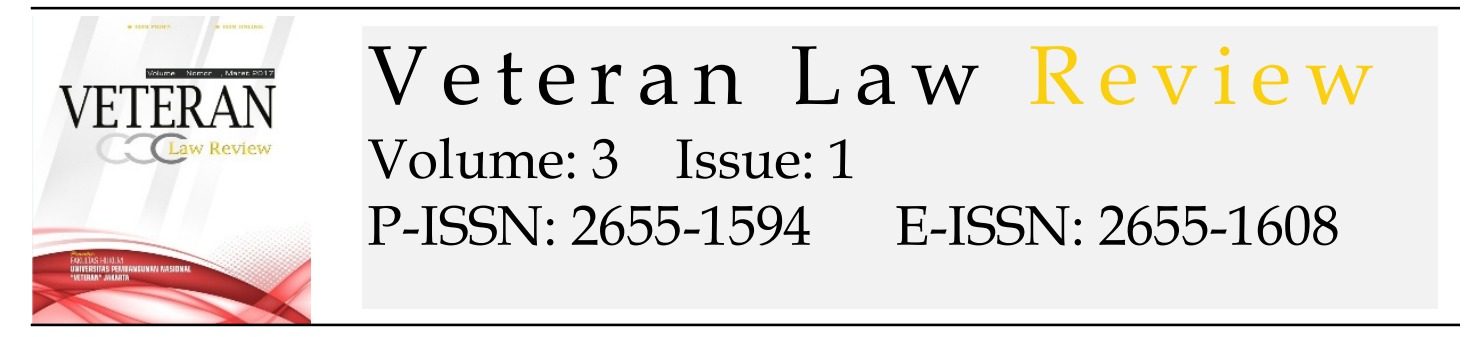

\title{
Juridical Analysis Of Employee Considerations As Administrative Competition Agency
}

\section{Robinsar Marbun}

Faculty of Law, Universitas Pembangunan Nasional Veteran Jakarta, E-mail: robinsar.marbun63@gmail.com

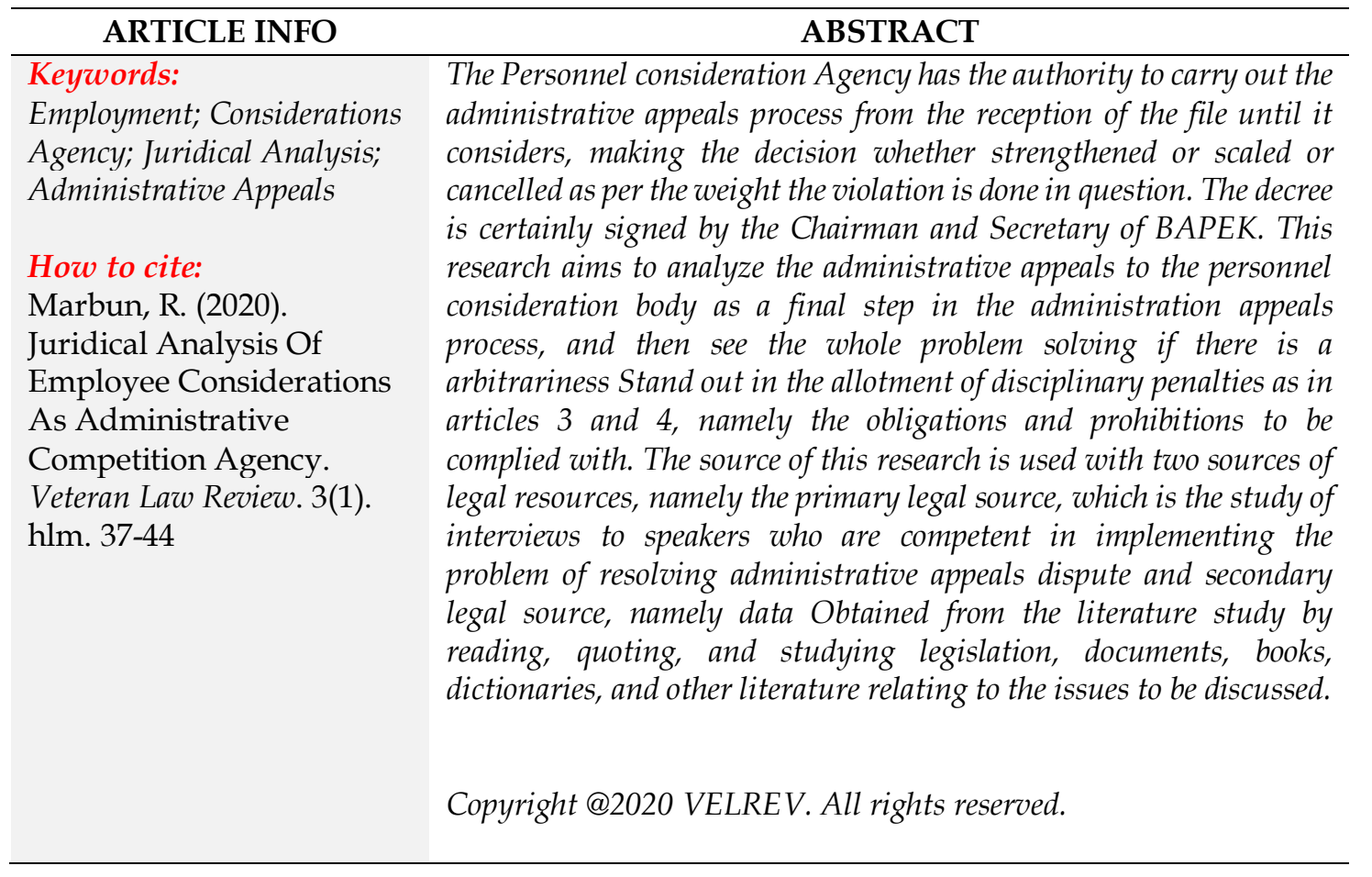

\section{Introduction}

Since the proclamation of the independence of the Republic of Indonesia on August 17, 1945 until now, the position and role of the Civil Servants (Pegawai Negeri Sipil) is important and decisive, because the Civil Servants are elements of the state apparatus that carry out governance and development in order to achieve national goals. ${ }^{1}$ The national objective as referred to in the Preamble of the 1945 Constitution (Pembukaan Undang - Undang Dasar Tahun 1945) is to protect all Indonesians and all Indonesian bloodspots and to advance public welfare, educate the nation's life, and participate in carrying out world order based on freedom, eternal peace and social justice. ${ }^{2}$ In achieving national goals can only be achieved if the State is orderly and safe, national development that is planned in a directed and realistic manner and carried out in stages, is serious, efficient and effective. The purpose of national development (national

1 H. Nainggolan. (1983) .Civil servants ' construction. The 4th mold. Bakn. page. 23.

2 th paragraph on opening of Constitution 1945 of the Republic of Indonesia. 
establishment aim) is to realize a just and prosperous society that is equitable and balanced between material and spiritual based on Pancasila within the Unitary State of the Republic of Indonesia. ${ }^{3}$

Beside that, the way of government administration and the implementation of national development mainly depend on the state apparatus, government apparatus, or as a political institution, meaning that it covers organs within the Government, starting from the President, the Minister (including the Secretary General, Director General, Inspector General, Head of Agency, Head of Institution Non-Ministerial Governments, Governors, Regents, Mayors and so on). ${ }^{4}$ Dynamic service or service certainly includes the whole process of collaboration between two people or more doing work that has been determined based on a certain rationality to achieve the goals set previously. ${ }^{5}$

Civil servants as an element of the state apparatus, state servants and civil servants who live in the middle of the community and work for the benefit of the people are therefore in need of proper construction. In the exercise of good governance, it should be possible to establish the compatibility between business interests and personal interests as individuals. If there is a difference between a business interest and a personal interest as an individual in a job then Sevice as Civil Servants interests are a priority. Talking about the importance of a Service is of course in accordance with the basic tasks and functions that a leader provides to a subordinate to perform within the scope of his or her job.

If a Civil Servant does not work, does not carry out the tasks entrusted to him, does not obey the laws and regulations and official regulations, then the Civil Servant will be disciplined according to the type of violation. If violations committed by a Civil Servant result in him being sentenced to one of the penalties in accordance with Article 7 paragraph (2), (3) and (4) Government Regulation Number 53 Year 2010 concerning Discipline of Civil Servants will result in an employee dispute. Civil Servants who were sentenced to discipline in the form of dismissal may submit administrative appeals to the Personnel Advisory Board either through the hierarchy or directly to the Personnel Advisory Agency (BAPEK) within a period of 14 (fourteen) days from the date the relevant person receives the disciplinary sentence. ${ }^{6}$ The Administrative Appeal itself is submitted in writing and must contain the reasons for the administrative appeal. But until now the response is still often a hindrance to the processing of administrative efforts submitted by Civil Servants who were dismissed with respect not at their own request as a civil servant.

\footnotetext{
${ }^{3}$ Republic of Indonesia. Explanation of Law number 8 year 1974 about the fundamentals of personnel. Additional Gazette of State Gazette of the Republic of Indonesia number 3041.

4 .S. T Kansil. (2000), Introduction to Indonesian law and legal sciences. Publisher: PN Balai Pustaka. page. 443.

${ }^{5}$ Sondang P. Siagian. (1974), Philosophy of Administration. The seventh mold. Jakarta: PT. Gunung Agung. page. 3.

${ }^{6}$ Republic of Indonesia. Government Regulation No. 53 year 2010 about civil servants ' discipline. State Gazette of the Republic of Indonesia year 2010 number 74 and addition to State Gazette Republic Indoesia number 5135.
} 
In addition to the need for a response, there are several other requirements that must be fulfilled such as: Minutes of Examination, Attendance List, Proposal for Disciplinary Punishment of the relevant Civil Servants as well as other materials related to the disciplinary punishment. Not only that, sometimes staffing disputes can occur, such as a staff member or typist, typing names, NIPs, place of birth, gender, religion, class of space, years of service, etc. but once given to the Chairperson, they are not re-examined and signed immediately after that it is immediately given a stamp and the letter number is then sent to the person concerned.

Personnel Advisory Agency (Badan Pertimbangan Kepegawaian next sentances will be calles as BAPEK) itself is directly under and accountable to the President. The main tasks of the BAPEK are:

a. Checking and making decisions regarding Administrative Appeals submitted by Civil Servants with the rank of Primary Leaders of Space Groups IV / d or below except for Regional Secretaries in Provinces and Middle Senior Leadership Offices, disciplinary penalties that can be imposed on them in the form of Dismissal with Respect not at your own request as Civil servants.

b. Give consideration to the President regarding the proposal to impose disciplinary termination with Respect Not Respectful At Your Own Request and Respect Not Respectful as a Civil Servant for Civil Servants who occupy the position of Provincial Secretary and Middle Senior Leadership Positions, submitted by the Governor, Minister, Attorney General, Head of Non-Ministry Government Institutions.

On the other hand, the composition of the Staff Advisory Agency (BAPEK) determined consists of: ${ }^{7}$

a. Minister of Administrative Reform and Bureaucracy Reform as Chairperson and Member.

b. Head of the State Personnel Agency as Secretary and concurrent Member.

c. Cabinet Secretary as Member.

d. Young Civil Attorney General and State Administration of Republic Indonesia Attorney General's Office as a Member.

e. Head of the State Intelligence Agency as a Member.

f. Director General of Laws and Regulations at the Ministry of Law and Human Rights as a Member.

g. Chairperson of the Central Indonesian officer corps (Korps Pegawai Republik Indonesia) Management as a Member.

\section{Formulation of The Probleme}

As for the problems being explained, the Formulation of the problemes are:

1. How does the Jurisdiction of the Agency consider the Personnel as an administrative appeals body in accordance with the National Civil Appeal Law?

$7 \quad$ Ibid., 
2. How to resolve the matter of the Office of Personnel Officers in administering a disciplinary sentence to a civil servant who has not complied with the provisions?

\section{Method}

This research was conducted using the normative juridical method, by seeing, studying and understanding all elements of the data collected, then deeply examined any norms that govern the Personnel Advisory Agency (BAPEK) so that the institution can run as it should.

In this study, researchers used a qualitative analysis that emphasizes the content analysis approach. This is used on the basis of content relating to the research problem being focused and not widened to other problems.

\section{Main Heading of the Analysis or Results}

\subsection{Development of BAPEK}

In discussions with the Assistant Secretary of BAPEK, Andi Anto, SH, MH, M.Sc at the 5th Floor Block III Building BKN on September 6, 2019, suggested that the Personnel Advisory Board (BAPEK) should have changed its nomenclature to become the State Civil Apparatus Consideration Agency (Badan Pertimbangan Aparatur Sipil Negara its called BPASN) as specified in Article 129 of Law Number 5 Year 2014 concerning State Civil Apparatus, as follows: 8

Article 129:

(1) Disputes of the State Civil Appeal Officer are resolved through administrative efforts.

(2) The administrative efforts referred to in paragraph (1) consist of administrative objection and appeal.

(3) Objection as referred to in paragraph (2) shall be submitted in writing to the superior officer who has the power to punish by submitting the grounds of objection and the execution shall be communicated to the Officer responsible.

(4) The administrative appeal as referred to in paragraph (2) shall be submitted to the State Civil Appeals Agency.

(5) Further provisions on the administrative efforts and bodies of the State Civil Apparatus as referred to in paragraph (2) and paragraph (4) shall be governed by the Government Regulations.

Mr. Andi Anto also said that more than 5 (five) years of Law Number 5 of 2014 was enacted, but so far there has not yet been any Government Regulation concerning the State Civil Apparatus Advisory Board. This institution certainly has a main task that is very different from the main task of the

\footnotetext{
8 Republic of Indonesia Law Number 5 Year 2014 Concerning State Civil Apparatus Discipline of Civil Servants. Republic of Indonesia State Gazette of 2014 Number 6 and Supplement to Republic of Indonesia State Gazette Number 5494.
} 
Personnel Advisory Agency, where BPASN has the duty and function to receive Administrative Appeals for disciplinary and non-disciplinary violations as long as a Decree has been issued by the Employee Supervisory Officer for violations committed by the Civil Apparatus Within a period of 14 days from the receipt of said Decree by the State, an Administrative Appeal can be submitted to the State Civil Apparatus Advisory Board in accordance with applicable regulations.

\subsection{Badan Pertimbangan Kepegawaian (BAPEK)}

Disciplinary punishment in the form of Dismissal of Civil Servants for violating the provisions of Government Regulation Number 53 Year 2010, for Civil Servants who have received a Decree Dismissal as a Civil Servant counted 14 (fourteen) days from receipt of the Decree, the relevant person submits an administrative effort in the form administrative appeal to the Personnel Advisory Board. If civil servants are not satisfied with the BAPEK Decree, it can be submitted to the State Administrative Court in this case to the Jakarta State Administrative Court. ${ }^{9}$ Previously the BAPEK Decision was not received by the person concerned, then the related party filed a lawsuit to the TUN High Court or was called the First Level Court for Plaintiffs and Defendants, but since the issuance of the Supreme Court Circular Letter Number 4 of 2016 concerning the Imposition of the Formulation of the Plenary Meeting of the 2016 Supreme Court Guidelines for Implementation of Duties for the Court established on December 9, 2016 and effective from the beginning of January 2017 until the end of December 2019. ${ }^{10}$

Otherwise, the circular letter is very contrary to Article 48 Act No. 5 year 1986 Jo. ACT Number 9 Year 2004 Jo. Act number 51 Year 2009. After the author conducts research in BAPEK office and asks the informant about the legal position of the Supreme Court Circular letter, the informant says that starting from the beginning of the year 2020 will be returned in accordance with article 51 of Law No. 5 The year 1986 is against the decision of BAPEK to be sued to PT. TUN Jakarta. The speaker also said that civil servants who commit severe violations and sentenced in the form of stops both disciplined and nondisciplinary will all be submitted to the Office of the State civil apparatus considerations to be taken Decision.

The existence of an Administrative Appeal is intended as an attempt or procedure by a civil servant who is dissatisfied with the State Business Decision in the Personnel, whose settlement is made by a higher authority or other agency of the Agency or State Business Agency . On the other hand, the objection is filed by the concerned Office of the Penal Officer within 21 (twenty-one) business days, if within 21 (twenty-one) working days the

\footnotetext{
9 Pandu Wibowo M.E. (2019), New bureaucracy designers welcomed the millennial ASN waves in bureaucracy. Publisher: Phoenix Publisher. page. 13-14.

10 Circular letter of the Supreme Court of the Republic of Indonesia number 4 year 2016 concerning the implementation of the formulation of the plenary meeting of the Supreme Court room year 2016 as a guideline for implementation of duty to the court.
} 
decision is not taken by the competent Office. The administrative effort itself can be illustrated in accordance with Figure 1 below:

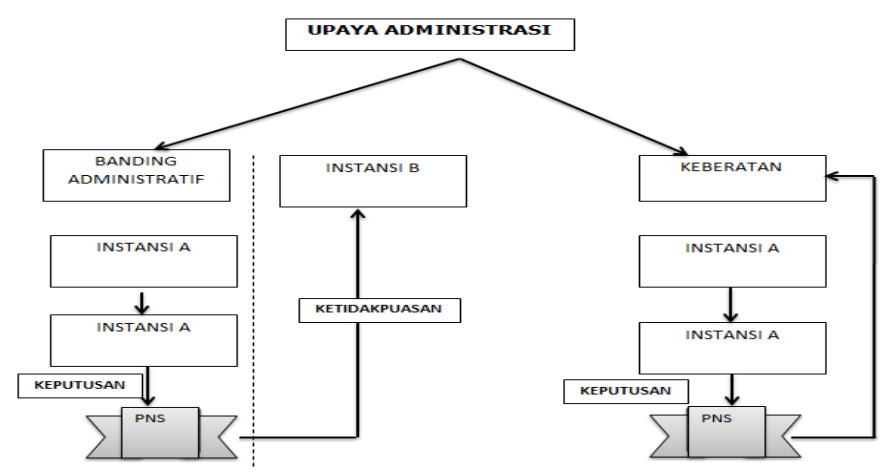

Gambar 1. Alur Upaya Administratif Sengketa Kepegawaian (Sumber: Alur Upaya Administrasi dari Sengketa Kepegawaian)

Until now there is still no Government Regulation governing administrative efforts and the State Civil Apparatus Advisory Board, and until now there is also no State Civil Apparatus Advisory Board. The State Civil Apparatus Advisory Board is different from the Personnel Advisory Agency (BAPEK), although its name is almost the same. This institutional difference has implications for the attributive authority possessed by the State Civil Apparatus Advisory Board so that it cannot be interpreted differently, because at present there is a legal vacuum related to dispute resolution of the Civil Service Officials. Indeed, the dispute resolution mechanism still refers to the old regulations, even though they should be revoked and no longer used or the principle of lex posteriori derogate legi priori applies. In its implementation, the dispute of personnel dispute also faces several problems because it still uses the old regulations, especially in matters in filing administrative appeals which in the new regulations are addressed to the State Civil Apparatus Advisory Board (Aparatur Sipil Negara next word will be calles as ASN) unlike the old regulations addressed to the Advisory Agency Staffing It will also cause problems if the applicant is a Government Employee with a Work Agreement (Pejabat Pembina Kepegawaian next word will be called PPPK), because PPPK is not regulated in the old legislation. For example, if the PPPK will file an administrative appeal, it must go through the ASN Advisory Board, but it is an obstacle when seen in the current conditions, where technical regulations governing the ASN Advisory Board have not been issued, then that will cause problems.

In the legal protection itself must be realized in the form of legal certainty. To realize the legal certainty itself one of them is the existence of regulations that function to provide certainty over the position, rights and obligations. The existence of legal certainty is also a hope for justice seekers of the arbitrary actions of law enforcement officials who sometimes are always arrogant in carrying out their duties as law enforcers. With the existence of legal certainty, the public will know about their rights and obligations according to the law. Without legal certainty, people will not know what to do, do not know their actions are right or wrong, prohibited or not prohibited by law. This legal 
certainty can be realized through good and clear normalization in a law and its application will also be clear.

In other words, legal certainty means that the law is correct, the subject and the object and the threat of punishment. Therefore, if the Government Regulation regarding administrative efforts and the ASN Advisory Agency has not been established so that there is no legal certainty regarding the facilities provided for the State Civil Apparatus especially with the PPPK in the case of filing disputes related to administrative appeals, which this will only lead to disputes or conflict over government actions that have not yet issued the Government Regulation. According to Utrecht, legal certainty contains two meanings, namely:

1. The existence of general rules that make individuals know what actions may or may not be done.

2. Legal security for individuals from the arbitrariness of the government because with the existence of general rules that individuals can know what may be charged or done by the State to individuals. ${ }^{11}$

\section{Conclusion}

From the analysis above the author took several conclusions including:

Juridical provisions governing the formation of the Personnel Advisory Board have been amended three times, namely: (1) Presidential Decree Number 67 of 1980 concerning Personnel Advisory Board, (2) Presidential Decree Number 71 of 1998 concerning Amendment to Presidential Decree Number 67 of 1980 regarding the Personnel Advisory Board, (3) Government Regulation of the Republic of Indonesia Number 24 of 2011 concerning Personnel Board. Whereas Article 16 of the Government Regulation of the Republic of Indonesia Number 24 of 2011 states that when this Government Regulation came into force, Presidential Decree Number 67 of 1980 concerning the Personnel Advisory Board as amended by Presidential Decree Number 71 of 1998 concerning Amendment to Presidential Decree Number 671980 concerning the Personnel Advisory Agency, revoked and declared invalid.

If there is an arbitrariness by the Civil Service Officers in disciplinary punishment to the State Civil Apparatus, then the right to defend themselves will be granted through administrative efforts which can be done in several ways, namely: (1) Objection, submitted in writing to the superior officer the authority to punish by including the reasons for the objection, and a copy delivered to the authorized official to punish, (2) Administrative Appeals, can be submitted when severe disciplinary punishment in the form of Dismissal With Respect Not At Your Own Request as a Civil Servant and Dismissal Dismissal as a Civil Servant by the Personnel Management Officer or the Governor, and (3) Lawsuit to the State Administrative Court, if the administrative legal remedies have been taken and the parties concerned are

11 Jonaedi Efendi , Gunadi and Fifit, (2016), Dictionary of popular legal terms. Publisher: Prenadamedia Group. page. 225. 
still not satisfied, then the matter can be sued and submitted to the State Administrative High Court.

\section{References}

4th paragraph Preamble of the 1945 Constitution of the Republic of Indonesia Republic of Indonesia. Explanation of Law Number 8 of 1974 concerning Personnel Principles. Supplement to the State Gazette of the Republic of Indonesia Number 3041.

Republic of Indonesia. Government Regulation Number 53 Year 2010 Concerning Discipline of Civil Servants. Republic of Indonesia State Gazette Number 74 of 2010 and Supplement to Republic of Indonesia State Gazette Number 5135.

Republic of Indonesia. Government Regulation Number 24 of 2011 concerning Personnel Advisory Board, State Gazette of the Republic of Indonesia of 2011 Number 45 and Supplement to State Gazette of the Republic of Indonesia Number 5210.

Republic of Indonesia Law Number 5 Year 2014 Concerning State Civil Apparatus Disciplined Civil Servants, State Gazette of the Republic of Indonesia Year 2014 Number 6 and Supplement to the Republic of Indonesia State Gazette Number 5494.

A.E. Manihuruk. Development of Civil Servants in Development. Prisma Number 4. August 1974. Year III.

Circular of the Supreme Court of the Republic of Indonesia Number 4 of 2016 concerning the Imposition of the Formulation of the Results of the Plenary Meeting of the 2016 Supreme Court Room as a Guide to Implementing Duties for the Court.

C.S.T Kansil. Introduction to Indonesian Law and Legal Studies. Publisher: PN Balai Pustaka.

Jonaedi Efendi, Dr. Ismu Gunadi Widodo, and Fifit Fitri Lutfianingsih, Dictionary of Popular Legal Terms. Publisher: Prenadamedia Group. 2016

H. Nainggolan. Development of Civil Servants. 4th printing. BAKN. 1983.

Pandu Wibowo M.E. New Bureaucracy Designer Welcomes Millennial ASN Wave in Bureaucracy. Publisher: Phoenix Publisher. 2019.

Sovia Hasanah, Flow of State Administration Dispute Settlement. 2016. Quoted from: www.hukumonline.com.

Sondang P. Siagian. Administrative Philosophy. Seventh printing. PT. Holy mountain. Jakarta: 1974. 